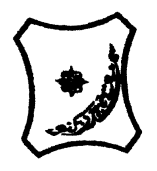

Bayero Journal of Pure and Applied Sciences, 12(1): 412 - 418

ISSN $2006-6996$

\title{
INFLUENCE OF DIETHYLENE TRIAMINE PENTA ACETIC ACID (DTPA) AMENDMENT ON THE UPTAKE OF SOME ESSENTIAL TRACE ELEMENTS BY Amaranthus hybridus $L$.
}

\author{
${ }^{2}$ Dagari, M. S., ${ }^{1}$ Musa, M. S. ${ }^{*}$ and ${ }^{1}$ Musa, I. A. \\ ${ }^{1}$ Department of Pure and Industrial Chemistry, Faculty of Physical Sciences, College of Natural and \\ Pharmaceutical Sciences, Bayero University Kano, P.M.B. 3011, Nigeria. \\ ${ }^{2}$ Department of Chemistry, Faculty of Science, Federal University Gashua, Yobe State, Nigeria. \\ *Corresponding author: m smusa@yahoo.com; msmusa.chm@buk.edu.ng; +2348060899099
}

\section{ABSTRACT}

The present study was aimed at determining the potential in the uptake and translocation of essential trace elements by Amaranthus hybridus $L$. seedlings and the effects of added 0.0025M DTPA as a bioremediation technology to increase the contents of trace elements in edible parts. Four week old Amaranthus hybridus L. seedlings were transplanted in hydroponic solution treated with copper and zinc and then monitored in a greenhouse for $72 \mathrm{hr}$ where significant changes in fresh weights were observed. The study was divided into two experiments first batch contains chelate and second batch contain unchelated treatments in three different combination of copper, zinc and Cu/Zn treatments. $\mathrm{Cu}^{2+}$ was restricted in the roots and no significant changes $(p>0.05)$ in the accumulation of $\mathrm{Cu}^{2+}$ was observed with respect to addition of DTPA to different concentration compared to unchelated treatments. However, accumulation and transportation of $\mathrm{Zn}^{2+}$ from roots to shoots was increased significantly $(p<0.05)$ to $2-3$ fold after DTPA application compared to unchelated treatments as it helped to increase the metal bioavailability. Furthermore, in $\mathrm{Cu} / \mathrm{Zn}$ combination, unchelated $\mathrm{Cu}^{2+}$ was found to accumulate more when compared to the chelated with the same $\mathrm{Cu}^{2+}$ concentration. Likewise, unchelated $\mathrm{Zn}^{2+}$ was significant/y translocated as compared with chelateassisted treatments of same zinc concentration. This indicates that in the presence of copper, zinc uptake was favorably translocated. Translocation factor was calculated to find relation with metal uptake in Amaranth hybridus $L$. seedlings.

Keywords: Essential elements, DTPA amendment, hydroponic, Amaranthus hybridus L.

\section{INTRODUCTION}

Heavy metals are important environmental pollutants that are of serious concern for environmental and toxicological reasons. They can affect a wide list of physiological and biological parameters in plants. Their toxicity also varies based on the plant species (Kalaivanan and Ganeshamurthy, 2016), the metal in question, its concentration and chemical form. Researches have been conducted extensively to determine the effects of toxic heavy metals in plants and the use of chelating agent application to clean up contaminated sites through phytoremediation (Jonak et al., 2004; Rout and Das, 2003). Copper $\left(\mathrm{Cu}^{2+}\right)$ and Zinc $\left(\mathrm{Zn}^{2+}\right)$ are both essential plant nutrients and have positive impact on plant development and yield (Chetan and Ami, 2015; Broadley et al., 2007; Arif et al., 2012).

Zinc induces oxidative stress with increasing concentration and prolonged exposure (Roy et al., 2005; D'souza and Devaraj, 2012). Being a non-redox transition metal, zinc plays important role as a structural co-factor, due to its high affinity for proteins (Maret and $\mathrm{Li}, 2009$ ). While $\mathrm{Zn}$ is a non redox transitional metal, $\mathrm{Cu}$ on the other hand, is a redox active transition metal that is involved in many physiological processes in plants (Martins and Mourato, 2006; Yruela, 2005). Copper accumulation in soils can be due to natural soil properties and agronomical activities. It may affect species differently and can cause diverse effects at which the metal was applied, the concentration of $\mathrm{Cu}$, and the duration of action. (Kaplan, 1999; Halliwell and Gutterridge, 1984).

Plants take heavy metals from soil solution into their roots. After entry into roots, metal ions can either be stored in the roots or translocated to the shoots primarily through xylem vessels where they are mostly deposited in vacuoles (Prasad, 2005). Plants use different mechanisms in terms of metal uptake by their roots based on plant species. These mechanisms can be due to absorption, redox potential, organic matter, $\mathrm{pH}$, redox reactions, exchange capacity, temperature and humidity. 
Special Conference Edition, November, 2019

Some plants take up metal complexes in the roots via the inside of the plasma membrane in which water and low molecular weight solutes freely diffused known as symplastic pathway (Johnson and Singhal, 2015). The metal uptake via the roots is related to the free ion concentration in solution around the roots. In this case metal is adsorbed to cation exchange sites which are located on the surface of the roots and within the cells in the roots (Nowack et al., 2005; Lou et al., 2008; Bell et al., 1991).

After subsequent metal mobilization in rhizosphere, metals are first taken into the root apoplast which is a free diffusion space outside the plasma membrane. Some of the total amount of metal take-up is transported into the cells, while some are transported further into the apoplast and some are bound to the cell wall substances.

When the values of the leaves concentration are found to be in the same range as those in the roots, the metal uptake might be through apoplastic (passive) pathway (Lou et al., 2008). Metal uptake mechanisms can also be through root symplast pathway into xylem apoplast and is possibly determined by transpiration pump (Williams et al., 2000).

In this study, diethylenetriamine penta acetic acid (DTPA) was used to increase the metal uptake by the plant species. The research is aimed at investigating the influence of DTPA amendment on the uptake of $\mathrm{Cu}^{2+}$ and $\mathrm{Zn}^{2+}$ by Amaranthus hybrids $\mathrm{L}$. replanted in hydroponic solutions.

\section{MATERIALS AND METHODS \\ Sampling Site and Plant Culture}

The field experiment was carried out in the Department of Agronomy farm, Bayero University, Kano with coordinates; latitude $8^{\circ}$ $22^{\prime}$, to $9^{\circ} 25^{\prime}$, North and longitude $11^{\circ} 57^{\prime}$ to $12^{\circ}$ 00' East. Amaranthus hybridus L. seeds were planted in the department of agronomy farm in October, 2017 and ground water was used during a four-week period. The fresh weight of the four weeks old Amaranthus hybridus L. seedlings were determined by weighing the seedlings after blotting off extra moisture and each seedling with similar weights were then replanted in hydroponic solution ( $\mathrm{pH} 4.5$ - 5.5) and kept in a greenhouse which contained the following nutrients: 0.0075 moldm $^{-3} \mathrm{KI}, 0.05$ moldm ${ }^{-3} \mathrm{Ca}\left(\mathrm{NO}_{3}\right)_{2} .4 \mathrm{H}_{2} \mathrm{O}, 20.10$ moldm $^{-3} \mathrm{H}_{3} \mathrm{BO}_{3}$, 0.10 moldm $^{-3} \mathrm{KNO}_{3}, 0.05 \mathrm{moldm}^{-3} \mathrm{MgSO}_{4} \cdot \mathrm{H}_{2} \mathrm{O}$, $0.10 \mathrm{moldm}^{-3} \mathrm{FeCl}_{3} .6 \mathrm{H}_{2} \mathrm{O}, 0.05 \mathrm{moldm}^{-3}$
$\mathrm{Na}_{2} \mathrm{H}_{2} \mathrm{P}_{2} \mathrm{O}_{7}, 0.05$ moldm $^{-3} \mathrm{MnSO}_{4} . \mathrm{H}_{2} \mathrm{O}$, (Libia and Fernando, 2012), copper and zinc in five levels $\left(0.000,0.0025,0.005,0.0075\right.$ and $\left.0.025 \mathrm{mg} \mathrm{L}^{-1}\right)$ as $\mathrm{Cu}\left(\mathrm{NO}_{3}\right)_{2}$ and $\mathrm{Zn}\left(\mathrm{NO}_{3}\right)_{2}$ respectively. The concentration of DTPA used was $0.0025 \mathrm{M}$. Amaranthus hybridus L. seedlings was harvested after $72 \mathrm{hr}$. The roots were carefully rinsed by submerging in 0.10 moldm $^{-3} \mathrm{HNO}_{3}$ for three consecutive times and rinsed with deionised water. The plants were transported in dark polythene bags to the laboratory from the harvest site. The fresh weight of plant sample after harvest was recorded and air-dried in the laboratory and oven dried at $60^{\circ} \mathrm{C}$ for $48 \mathrm{hr}$ until a constant weight was reached. Plant root and shoot were separated for metal accumulation assessment using AAS.

\section{Analysis of the plant samples}

Amaranthus hybridus L. seedlings were separated and ground to fined powder using wooden mortar and pestle. 1g of Amaranthus hybridus $\mathrm{L}$. shoot powder of each treatment was weighed and transferred into a clean dried porcelain crucible, similarly, $1 \mathrm{~g}$ of the root powder for each treatment was weighed and transferred into a clean dried porcelain crucible. The weight of porcelain crucible and the plant tissue were then recorded and inserted in a muffle furnace. The muffle furnace temperature was set at $450^{\circ} \mathrm{C}$, the door was first left ajar for few minutes to let smoke escape completely, closed and left to stay for $4 \mathrm{hr}$. After $4 \mathrm{hr}$, the ash was removed and cooled in a desiccator. The weight of the porcelain crucible together with the ash was recorded. $10 \mathrm{~cm}^{3}$ of $0.10 \mathrm{M}$ $\mathrm{HNO}_{3}$ was used to dissolve the ash and the contents was filtered using filter paper into a 50 $\mathrm{cm}^{3}$ volumetric flask and made to the mark with $0.10 \mathrm{M} \mathrm{HNO}_{3}$ and the contents were transferred into a labelled polythene bottles for AAS analysis. The $\mathrm{Zn}^{2+}$ and $\mathrm{Cu}^{2+}$ content in the roots and shoots were analyzed using Atomic Absorption Spectrophotometer at $213.9 \mathrm{~nm}$ and $324.7 \mathrm{~nm}$ wavelength respectively. The concentrations of $\mathrm{Zn}^{2+}$ and $\mathrm{Cu}^{2+}$ were reported as $\mathrm{mg} \mathrm{kg}^{-1}$ dry weight (Dagari and Umar, 2017).

\section{Statistical Analysis}

Analysis of variance (ANOVA) was carried out using SPSS software to check the accuracy and validity of the results. All data were treated using Excel 2016 program for windows and significance test were performed using One-way ANOVA at $95 \%$ confidence level. 
Special Conference Edition, November, 2019 RESULTS AND DISCUSSION Changes in Fresh Weight

Copper and zinc toxicity has a significant effect on the fresh biomass of smooth amaranth seedlings, there was a significant decrease in the fresh biomass from all the treatment. Generally, the change in total fresh weight of Amaranthus hybridus L. seedlings replanted in nutrient solution after three days of each treatment was in the order of $\mathrm{Cu}>\mathrm{Zn} / \mathrm{Cu}>\mathrm{Zn}$ DTPA $>$ Zn> Cu-DTPA > Zn/Cu-DTPA. Changes in fresh weights of all treatments were significant $(p<0.05)$ with respect to addition of $\mathrm{Zn}^{2+}$ and $\mathrm{Cu}^{2+}$ concentration in chelated and unchelated forms (Liao et al, 2000).

Table 1: Concentration of Cu2+ in five levels for chelated and unchelated treatments. *DW - Dry Weight

\begin{tabular}{lccl}
\hline $\mathbf{m g ~ k g} \mathbf{~}^{-1} \mathbf{C u}^{2+}(\mathbf{D W})$ & Cu Shoot & Cu Root & $\Delta$ Fresh Weight $(\mathrm{g})$ \\
\hline $0.000 \mathrm{Cu}^{2+}$ & $1.044 \pm 0.277$ & $1.339 \pm 0.280$ & $-16.325 \pm 1.396$ \\
$0.0025 \mathrm{Cu}^{2+}$ & $0.851 \pm 0.286$ & $1.555 \pm 0.370$ & $-10.659 \pm 3.341$ \\
$0.005 \mathrm{Cu}^{2+}$ & $1.505 \pm 0.472$ & $1.301 \pm 0.521$ & $-14.875 \pm 5.357$ \\
$0.0075 \mathrm{Cu}^{2+}$ & $1.138 \pm 0.085$ & $2.509 \pm 0.450$ & $-18.628 \pm 1.494$ \\
$0.025 \mathrm{Cu}^{2+}$ & $0.790 \pm 0.147$ & $1.997 \pm 0.307$ & $-32.918 \pm 1.497$ \\
$0.0025 \mathrm{Zn}^{2+} \mathrm{Cu}^{2+}$ & $0.745 \pm 0.115$ & $1.326 \pm 0.937$ & $-8.481 \pm 1.678$ \\
$0.005 \mathrm{Zn}^{2+} \mathrm{Cu}^{2+}$ & $1.364 \pm 0.555$ & $2.130 \pm 0.640$ & $-9.924 \pm 1.038$ \\
$0.0075 \mathrm{Zn}^{2+} \mathrm{Cu}^{2+}$ & $1.055 \pm 0.154$ & $2.363 \pm 0.330$ & $-15.598 \pm 3.929$ \\
$0.025 \mathrm{Zn}^{2+} \mathrm{Cu}^{2+}$ & $1.121 \pm 0.098$ & $3.120 \pm 0.663$ & $-18.603 \pm 1.429$ \\
$0.0025 \mathrm{Cu}^{2+}$ DTPA & $0.746 \pm 0.212$ & $1.264 \pm 0.223$ & $-9.921 \pm 2.924$ \\
$0.005 \mathrm{Cu}^{2+}$ DTPA & $0.887 \pm 0.170$ & $2.157 \pm 0.159$ & $-9.471 \pm 0.971$ \\
$0.0075 \mathrm{Cu}^{2+}$ DTPA & $1.011 \pm 0.524$ & $1.753 \pm 0.324$ & $-20.982 \pm 1.910$ \\
$0.025 \mathrm{Cu}^{2+}$ DTPA & $1.183 \pm 0.073$ & $1.379 \pm 0.147$ & $-15.881 \pm 2.116$ \\
$0.0025 \mathrm{Zn}^{2+} \mathrm{Cu}^{2+}$ DTPA & $0.730 \pm 0.160$ & $1.625 \pm 0.540$ & $-11.753 \pm 5.702$ \\
$0.005 \mathrm{Zn}^{2+} \mathrm{Cu}^{2+}$ DTPA & $0.850 \pm 0.276$ & $2.299 \pm 0.277$ & $-11.528 \pm 1.442$ \\
$0.0075 \mathrm{Zn}^{2+} \mathrm{Cu}^{2+}$ DTPA & $0.759 \pm 0.141$ & $1.295 \pm 0.262$ & $-9.895 \pm 3.627$ \\
$0.025 \mathrm{Zn}^{2+}+\mathrm{Cu}^{2+}$ DTPA & $1.249 \pm 0.170$ & $1.538 \pm 0.526$ & $-18.429 \pm 0.797$ \\
\hline
\end{tabular}

Accumulation of Copper (Cu) in Amaranthus hybridusseedlings

The result for chelate-assisted and unchelated $\mathrm{Cu}^{2+}$ (Table 1) showed increase in uptake by Amaranthus Hybridus L. when compared with the control. However, most of the $\mathrm{Cu}^{2+}$ were retained in the roots (Liao et al., 2000; Ye et al., 1997). It is observed that in the treatments between chelate-assisted and unchelated $\mathrm{Cu}^{2+}$, unchelated $\mathrm{Cu}^{2+}$ was found to accumulate more $\mathrm{Cu}^{2+}$ in the rooting media when compared to chelate assisted $\mathrm{Cu}^{2+}(\mathrm{P}>0.05)$ (Kumar, et al., 2012). This can be an indication of free metal ion exchange in which the metal uptake via the roots are adsorbed to cation exchange sites. (Nowack et al., 2005; Roger, 1991). DTPA tends to inhibit the absorption of $\mathrm{Cu}$ as in similar findings byYu et al., (2014). Therefore, chelateassisted treatments were found to reduce $\mathrm{Cu}^{2+}$ absorption as compared to unchelated treatments. These findings were supported by Yu et al., (2014) and Rengel, (1999). From the results of this experiment it can be seen that most of the $\mathrm{Cu}^{2+}$ is accumulated in the roots for both treatments with/without DTPA. In the experiment carried out by Johnson and Singhal, (2015) it was reported that "When membrane permeability is low, endodermal damage increases shoot $\mathrm{Cu}^{2+}$ accumulation due to higher apoplastic bypass flow." Whereas, in this study decrease in shoot $\mathrm{Cu}^{2+}$ accumulation might be due to low apoplastic bypass flow and that the endodermal might be fairly intact in Smooth Amaranth (Amaranthus hybridus L.) seedlings.

Accumulation and uptake of Zinc (Zn) in Amaranthus hybridus L. Seedlings

Smooth amaranth was found to accumulate $\mathrm{Zn}^{2+}$ in the above-ground biomass in all the different treatments with different levels of absorption and translocation to the above aerials parts (Table 2). The increasing levels of $\mathrm{Zn}^{2+}$ had favorably influenced the $\mathrm{Zn}^{2+}$ content of shoot in Amaranthus hybridus seedlings as evidenced by the increase in $\mathrm{Zn}^{2+}$ content when compared with root accumulation. This was supported by the reports of Ogunkunleet al.,(2013) and Zhihong et al.,(1998). The accumulation of unchelated $\mathrm{Zn}^{2+}$ treatments in Amaranthus hybridus $\mathrm{L}$. seedlings might be explained due to free ion activity at the surface of the roots. (Nowack et al., 2005; Rengel, 1999). This might also be due to nutritional contents of Amaranthus hybridus L. seedlings (Ogunkunle et al., 2013). 
Special Conference Edition, November, 2019

However, $\mathrm{Zn}-\mathrm{Cu}$ chelate-assisted was found to accumulate total $\mathrm{Zn}$ content in shoot than in all treatments (Table 2). The increase in chelateassisted metal uptake indicates"uptake is rate- limited by diffusion of the free ion to the root or cell surface." It also depends on the ligand type, ligand concentration in the solution media and ligand dissociation rate. (Degryse et al., 2006).

Table 2: Concentration of $\mathrm{Zn}^{2+}$ in five levels for chelated and unchelated treatments accumulated in shoots and roots and changes in fresh weight by Amaranthus hybridus $L$. (Mean \pm Stdev. of three replicates).

\begin{tabular}{|c|c|c|c|}
\hline $\mathrm{Zn}^{2+} \mathrm{mg} \mathrm{kg}^{-1} \mathrm{DW}$ & Zn Shoot & Zn Root & $\Delta$ Fresh Weight $(\mathrm{g})$ \\
\hline $0.000 \mathrm{Zn}^{2+}$ & $2.398 \pm 0.370$ & $1.315 \pm 0.520$ & $-16.325 \pm 1.396$ \\
\hline $0.0025 \mathrm{Zn}^{2+}$ & $2.974 \pm 0.305$ & $1.660 \pm 0.902$ & $-15.929 \pm 2.575$ \\
\hline $0.005 \mathrm{Zn}^{2+}$ & $2.208 \pm 0.471$ & $1.851 \pm 0.575$ & $-24.261 \pm 3.080$ \\
\hline $0.0075 \mathrm{Zn}^{2+}$ & $2.009 \pm 0.285$ & $2.183 \pm 0.850$ & $-2.577 \pm 2.312$ \\
\hline $0.025 \mathrm{Zn}^{2+}$ & $2.770 \pm 0.831$ & $1.512 \pm 0.503$ & $-6.718 \pm 1.864$ \\
\hline $0.0025 \mathrm{Zn}-\mathrm{Cu}$ & $2.313 \pm 0.276$ & $2.381 \pm 0.558$ & $-8.481 \pm 1.678$ \\
\hline $0.005 \mathrm{Zn}-\mathrm{Cu}$ & $2.512 \pm 0.179$ & $1.260 \pm 0.361$ & $-9.924 \pm 1.038$ \\
\hline $0.0075 \mathrm{Zn}-\mathrm{Cu}$ & $2.544 \pm 0.630$ & $0.786 \pm 0.159$ & $-15.598 \pm 3.929$ \\
\hline $0.025 \mathrm{Zn}-\mathrm{Cu}$ & $3.849 \pm 0.899$ & $1.173 \pm 0.268$ & $-18.603 \pm 1.429$ \\
\hline $0.0025 \mathrm{Zn}^{2+}$ _DTPA & $3.096 \pm 0.865$ & $1.544 \pm 0.548$ & $-9.079 \pm 2.017$ \\
\hline $0.005 \mathrm{Zn}^{2+}$ _DTPA & $2.826 \pm 0.776$ & $0.801 \pm 0.031$ & $-12.933 \pm 0.882$ \\
\hline $0.0075 \mathrm{Zn}^{2+}$ _DTPA & $2.470 \pm 0.404$ & $0.857 \pm 0.164$ & $-14.830 \pm 1.221$ \\
\hline $0.025 \mathrm{Zn}^{2+}{ }_{-} \mathrm{D} T P A$ & $3.188 \pm 0.139$ & $1.216 \pm 0.203$ & $-18.362 \pm 2.004$ \\
\hline $0.0025 \mathrm{Zn}^{2+}+\mathrm{Cu}^{2+}$ DDTPA & $2.633 \pm 0.298$ & $1.562 \pm 0.130$ & $-11.753 \pm 5.702$ \\
\hline $0.005 \mathrm{Zn}^{2+}+\mathrm{Cu}^{2+}$ - DTPA & $2.603 \pm 0.378$ & $1.799 \pm 1.126$ & $-11.528 \pm 1.442$ \\
\hline $0.0075 \mathrm{Zn}^{2+}+\mathrm{Cu}^{2+}$ DTPA & $3.071 \pm 0.425$ & $2.244 \pm 0.222$ & $-9.895 \pm 3.627$ \\
\hline $0.025 \mathrm{Zn}^{2+}+\mathrm{Cu}^{2+}{ }_{\text {DTPA }}$ & $3.538 \pm 1.510$ & $2.166 \pm 0.069$ & $-18.429 \pm 0.797$ \\
\hline
\end{tabular}

*DW - Dry Weight

Translocation of Metals in Hydroponic Treatments by Amaranthus hybridus $L$. Seedlings

Translocation Factor (TF) was used to evaluate the potential of this species for phytoextraction. The TF is an indication of the ability of the plant to translocate metals from the roots to the aerial parts of the plant. Metals that are accumulated by plants and largely stored in the roots of plants are indicated by TF values $<1$, with values greater than indicates translocation to the aerial part of the plant (Marchiol et al, 2004). It is represented by the ratio:

$\mathrm{TF}=$ Metal concentration (Stems + Leaves) / Metal concentration (roots)

A translocation factor (TF) less than 1 categorizes the plant as heavy metal excluder. Whereas, a translocation index greater than 1 means a good amount of the metal in question is translocated (Marchiol et al., 2004).

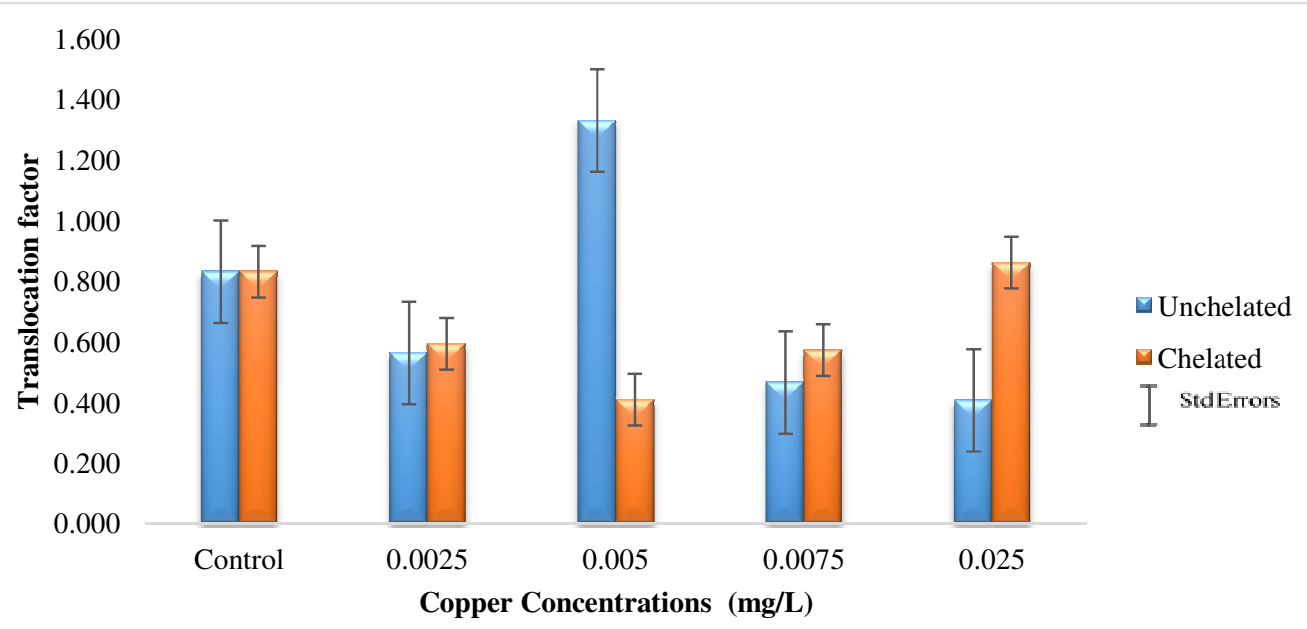

Figure 1: Translocation Factor (TF) of $\mathrm{Cu}^{2+}$ in Chelated and Unchelated Treatments by Amaranthus hybridus L. Seedlings Replanted in Hydroponic Solution. 
Special Conference Edition, November, 2019

It can be observed from Figure 1 that the treatment for chelated and unchelated $\mathrm{Cu}$ for different concentration $0.000,0.0025,0.005$, 0.0075 , and $0.025 \mathrm{mg} \mathrm{Cu} \mathrm{L}^{-1}$ on the TF values showed values less than one for all treatment except at $0.005 \mathrm{mg} \mathrm{Cu} \mathrm{L}^{-1}$ where the TF value was 1.330 but statistically was insignificant. The variance in accumulation in roots might suggest the presence of a translocation limiting process (Liao et al., 2000). The TF values are similar despite different $\mathrm{Cu}^{2+}$ concentrations which might be possibly due to a highly regulated reoxidation of cuprous $\mathrm{Cu}$ (I) to cupric $\mathrm{Cu}$ (II) and possibly a highly regulated mechanism of $\mathrm{Cu}^{2+}$ transport between roots and stems as stated by Ryan et al., (2013). Translocation factor of less than one in all $\mathrm{Cu}^{2+}$ treatments can also signify that Amaranthus hybridus L. can be categorized as an excluder of $\mathrm{Cu}^{2+}$.

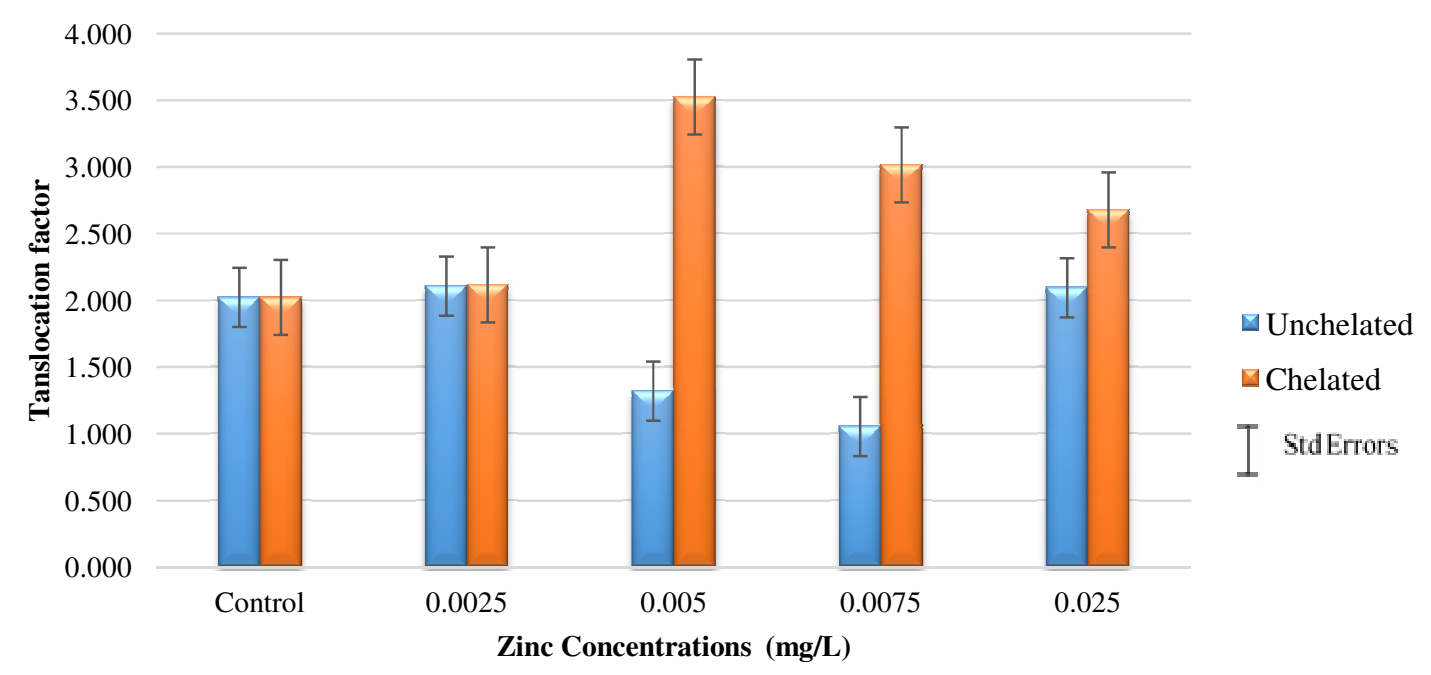

Figure 2: Translocation Factor (TF) of $\mathrm{Zn}^{2+}$ in Amaranthus hybridus $\mathrm{L}$. seedlinds grown in chelated and unchelated treatments of same $\mathrm{Zn}^{2+}$ concentration.

The TF values for chelated and unchelated $\mathrm{Zn}^{2+}$ treatment on Amaranthus hybridus L. seedlings in all conditions were higher than one which indicates that $\mathrm{Zn}^{2+}$ concentration in shoots is higher than in roots and the highest value observed of TF was $3.528 \pm 0.939$ at $0.005 \mathrm{mg} \mathrm{Zn}$ $\mathrm{L}^{-1}$ Chelate-assisted. The result of translocation of unchelated $\mathrm{Zn}^{2+}$ concentration were similar as reported by Ogunkunle et al., (2013) in which the increase in translocation might be due to the nutritional contents of the plants (Fig. 2). Whereas, the TF values of Chelate-assisted $\mathrm{Zn}^{2+}$ treatment showed high translocation of $\mathrm{Zn}^{2+}$ to the aerial parts of Amaranthus hybridus L. as compared with treatments of unchelated $\mathrm{Zn}^{2+}$ concentration. This indicate that the presence of DTPA enhanced translocation of $\mathrm{Zn}^{2+}$ in shoots of Amaranthus hybridus L. seedlings.

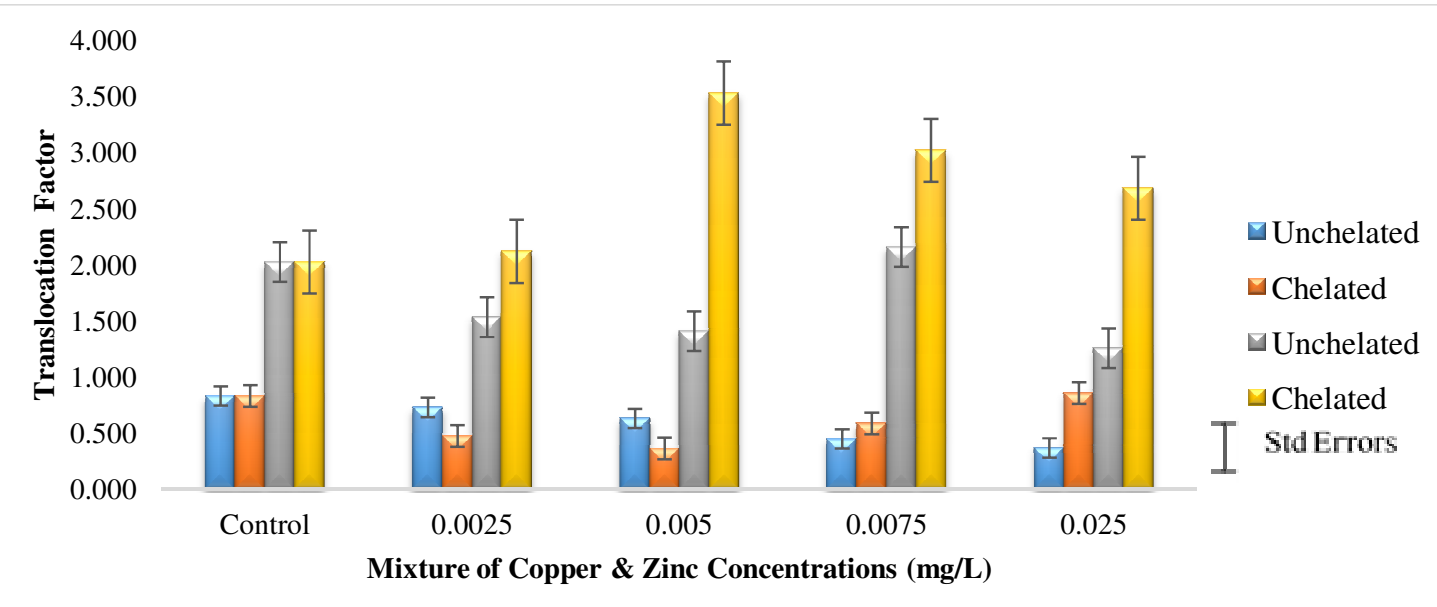

Figure 3:Translocation Factor of $\mathrm{Cu} / \mathrm{Zn}$ in Amaranthus hybridus $\mathrm{L}$. seedlings grown in chelated and unchelated treatments of same $\mathrm{Cu}^{2+} / \mathrm{Zn}^{2+}$ concentration. 
Unchelated $\mathrm{Cu}^{2+}$ treatments showed decrease in translocation compared to the control. While for chelated $\mathrm{Cu}^{2+}$ treatments, the trend showed a linear trend that is all the values were similarly to the control. The results for unchelated $\mathrm{Cu}^{2+}$ treatments were slightly insignificant $(P>0.05)$. In $(\mathrm{Zn} / \mathrm{Cu}) \mathrm{Zn}^{2+}$ unchelated treatments showed a steady increase in the translocation values (from $\left.0.0025-0.025 \mathrm{mg} \mathrm{Zn} \mathrm{L}^{-1}\right)$ with $(P<0.05)$. Furthermore, it was observed that $\mathrm{Zn}^{2+}$ in $(\mathrm{Zn} / \mathrm{Cu})$ treatments was significantly translocated in unchelated treatments, and it suppresses the translocation of $\mathrm{Cu}^{2+}(\mathrm{Zn} / \mathrm{Cu})$ in the same treatments (fig. 3). But, in chelated treatments translocation to aerial parts was restricted compared to unchelated treatments. This is an indication that DTPA inhibits the translocation of $\quad \mathrm{Zn}^{2+}$ and $\mathrm{Cu}^{2+}$ in combine treatments. Most metal chelate complexes were subsequently translocated to the aerial part of smooth amaranth which is consistent with the findings of Chen et al., (2012). The translocation in unchelated $\mathrm{Zn} / \mathrm{Cu}$ treatments showed higher increase in the translocation factor of $\mathrm{Zn}$ while at the same time a steady decrease in translocation of $\mathrm{Cu}$. The trend in translocation of unchelated $\mathrm{Zn} / \mathrm{Cu}$ combine can be explained due to

\section{REFERENCE}

Arif, M., Shehzad, M. A., Bashir, F. and Tasneem, M. (2012). "Boron, zinc and microtone effects on growth, chlorophyll contents and yield attributes in rice ( Oryza sativa L .) cultivar." African Journal of Biotechnology 14(48): 10851-10858.

Bell, P., Chaney, R. and Angle, J. (1991). "Free Metal Activity and Total Metal Concentrations as Indices of Micronutrient Availability to Barley [ Hordeum vulgare (L.) 'Klages]". Plant and Soil, 130(1-2): 5162.:

Broadley, M., White, P., Hammond, J., Zelko, I. and Lux, A. (2007). "Zinc in plants". New Phytologist, 173: 677-702.

Chen, K. F., Yeh, T. Y. and Lin, C. F. (2012). "Phytoextraction of $\mathrm{Cu}, \mathrm{Zn}$, and $\mathrm{Pb}$ Enhanced by Chelators with Vetiver ( Vetiveria zizanioides): Hydroponic and Pot Experiments".International Scholarly Research Network1, 1-12. https://doi.org/10.5402/2012/729693.

Chetan, A., and Ami, P. (2015). "Effects of Heavy Metals $(\mathrm{Cu}$ and $\mathrm{Cd}$ ) on Growth of Leafy Vegetables- Spinacia oleracea and Amaranthus caudatus Effects of Heavy Metals ( $\mathrm{Cu}$ and $\mathrm{Cd}$ ) on Growth of Leafy Vegetables- Spinacia oleracea and Amaranthus caudatus". International Research Journal of Environment Sciences, 4(6): 63-69. antagonistic effect between $\mathrm{Cu}$ and $\mathrm{Zn}$ and, possibly indicates that $\mathrm{Zn}^{2+}$ whether in combine state with $\mathrm{Cu}^{2+}$ or not the ligand was able to translocate in both conditions to above ground parts of Amaranthus hybridus $\mathrm{L}$.

\section{CONCLUSION}

Amaranthus hybridus $\mathrm{L}$. seedlings were found to accumulate high amount of copper in the root for both chelated and unchelated treatments than in the shoot. Copper was barely translocated to the aerial parts of the plant for chelated and unchelated treatment. DTPA amendment was found to inhibit the translocation of copper by the plant. Chelated treatments were observed to have high reduction in plant fresh weight as compared to unchelated copper treatments. Results also indicated high accumulation of zinc in the shoots than in the roots. Furthermore, there was high reduction in fresh weight for unchelated treatments than for chelated zinc treatments. The translocation factor for chelated treatments showed that, DTPA amendment enhanced the translocation of zinc in Amaranthus hybridus L. seedlings.

D'souza, R. M., and Devaraj, V. (2012). "Induction Of Oxidative Stress And Antioxidative Mechanisms In Hyacinth Bean Under Zinc Stress". African Crop Science Journal, 20(1): 17-29.

Dagari, M.S, and G.W Umar. (2017). "Impacts of EDTA on Uptake and Accumulation of $\mathrm{Cu}^{2+}$ by Spinach (Spinacia Oleracea L.) Seedlings Replanted in Hydroponic Solutions." ChemSearch Journal 8(1): 7480.

Degryse, F., Smolders, E., and Parker, D. R. (2006). Metal complexes increase uptake of $\mathrm{Zn}$ and $\mathrm{Cu}$ by plants: Implications for uptake and deficiency studies in chelatorbuffered solutions. Plant and Soil, 289(12): 171-185.

Halliwell, B., and Gutterridge, J. (1984). "Oxygen toxicity, oxy-gen radicals, transition metals and disease". Biochem. Journal, 219: 114.

Johnson, A., and Singhal, N. (2015). "Increased Uptake of Chelated Copper Ions by Lolium perenne Attributed to Amplified Membrane and Endodermal Damage". International Journal of Molecular Sciences, 16: 2526425284.

Jonak, C. Nakagami, H. and Hirt H. (2004). "Heavy metal stress. Activation of distinct mitogen-activated protein kinase pathways by copper and cadmium". Plant Physiol. 136: 3276-3283. 
Special Conference Edition, November, 2019

Kaplan, M. (1999) "Accumulation of $\mathrm{Cu}$ in soils and leaves of tomato plants in greenhouses in Turkey". Journal of Plant Nutrition 22: 237-244.

Kalaivanan, D. and Ganeshamurthy, A N. (2016). " Mechanisms of Heavy Metal Toxicity in Plants". Abiotic Stress Physiology of Horticultural Crops, 5: 85-102.

Kumar, A. A., Dipu, S. and Vincent, S. gnana thanga. (2012). "Effect of Chelating Agents in Phytoremediation of Heavy Metals". Remediation Journal, 134-148.

Libia I. Trejo-Téllez and Fernando C. GómezMerino (2012). "Nutrient Solutions for Hydroponic Systems, Hydroponics - A Standard Methodology for Plant Biological Researches". Dr. Toshiki Asao (Ed.), ISBN: 978-953-51-0386-8.

http://www.intechopen.com/books/hydrop onics-a-standardmethodology-for-plantbiological-researches/nutrient-solutionsfor-hydroponic-systems Retrieved: March, 2017

Liao, M. T., Hedley, M. J., Woolley, D. J., Brooks, R. R. and Nichols, M. A. (2000). "Copper uptake and translocation in chicory (Cichorium intybus L. cv. Grasslands Puna) and tomato (Lycopersicon esculentum Mill. cv. Rondy) plants grown in NFT system. I. Copper uptake and distribution in plants". Plant and Soil, 221: 135-142.

Marchiol, L., Assolari, S., Sacco, P. and Zerbi, G. (2004). "Phytoextraction of heavy metals by canola (Brassica napus) and radish (Raphanus sativus) grown on multicontaminated soil". Environ. Poll., 132: 21 - 27.

Lou, C., Shen, Z. and Li, X. (2008). "Hot NTA application enhanced metal phytoextraction from contaminated soil." Water Air Soil Pollut. 188: 127-137.

Maret, W., \& Li, Y. (2009). Coordination dynamics of zinc in proteins. Chem Rev, 109, 46824707.

Martins, Luisa Louro and Mourato, Miguel Pedro (2006). "Effect of Excess Copper on Tomato Plants: Growth Parameters, Enzyme Activities, Chlorophyll, and Mineral Content". Journal of Plant Nutrition, (29:12) 2179-2198.

Nowack, B., Wenger, K. and Tandy, S. (2005). Effects of Chelating Agents on Trace Metal Speciation and Bioavailability. ACS Symposium Series; American Chemical Society: Washington, DC, 204-224. https://doi.org/doi: $\quad 10.1021 /$ bk-20050910.ch012

Ogunkunle, C. O., Fatoba, P. O. and Awotoye, O. O. (2013). Root-shoot partitioning of copper, chromium and zinc in Lycopersicon esculentum and Amaranthus hybridus grown in cement-polluted soil.
Environmental and Experimental Biology, (11): 131-136.

Prasad, M., Narasimha V. (2005). "Nikelophilous plants and their significance in phytotechnologies." Braz. J. Plant Physiol., 17: 113-128.

Rengel, Z. (1999). Physiological responses of wheat genotypes grown in chelatorbuffered nutrient solutions with increasing concentrations of excess HEDTA. Plant and Soil, 215: 193-202.

Roger, J. (1991). Influence of Complexation on the Uptake by Plants of Iron, Manganese, Copper and Zinc. Journal of Experimental Botany, 42(237): 509-513.

Rout, G. and Das, P. (2003). "Effect of Metal Toxicity on Plant Growth and metabolism". Agronomie, EDP Sciences. 23 (1), pp.3-11. Doi:10.1051/agro: 2002073.hal-00885964

Roy, P., Niyogi, K. SenGupta, D. N. and Ghosh, B. (2005). "Spermidine treatment to rice seedlings recovers salinity stress-induced damage of plasma membrane and PMbound H1-ATPase in salt-tolerant and saltsensitive rice cultivars". Plant Sci. 168: 583-591

Ryan, B. M., Kirby, J. K., Degryse, F., Harris, H., Mclaughlin, M. J., Scheiderich, K. and Ryan, B. (2013). Copper speciation and isotopic fractionation in plants: uptake and translocation mechanisms. New Phytologist, 367-378.

Sharma R.K., Agrawal M. and Marshall F., (2009) Heavy metal contamination of soil and vegetables in suburban areas of Varanasi, India. Ecotoxicology and Environmental Safety, 66: 258-266.

Williams, L., Pittman, J. and Hall, J. (2000). "Emerging mechanism for heavy metal transport in plants."Biochem. Biophys Acta, 1465(1): 104-126.

Ye, Z., Baker, A. J. M., Wong, M. and Willis, A. J. (1998). Zinc, lead and cadmium accumulation and tolerance in Typha latifolia as affected by iron plaque on the root surface. Aquatic Botany, 61: 55-67.

Ye, Z., Bakeri, A., Wong, M. and Willis, A. (1997). Copper and nickel uptake, accumulation and tolerance in Typha latifolia with and without iron plaque on the root surface. New Phytologist, 136: 481-488.

Yruela, I. (2005). Copper in plants. Braz. J. Physiol., 17(1), 145-156.

Yu, X. Z., Wang, D. Q. and Zhang, X. H. (2014). Chelator-induced phytoextraction of zinc and copper by rice seedlings. Ecotoxicology, 23(4), 749-756.

Zhihong, Y., Alan J. M. Bakera., Ming-Hung W. and Arthur, J. W. (1998) "Zinc, lead and cadmium accumulation and tolerance in Typha latifolia as affected by iron plaque on the root surface" Aquatic Botany 61: 55 67. 